\title{
Failure of Hypoxic Pulmonary Vasoconstriction in the Canine Asthma Model
}

\author{
EFFECT OF PROSTAGLANDIN INHIBITORS
}

\author{
Martin A. Cohn, Horst Baier, and Adam Wanner, The Division of Pulmonary \\ Disease, Mount Sinai Medical Center, Miami Beach, Florida 33140
}

\begin{abstract}
A B S T R A C T Measurements of respiratory mechanics, arterial blood gases, and pulmonary vascular resistance were made before and $15 \mathrm{~min}$ after inhalation challenge with Ascaris suum extract in dogs with natural sensitivity to this antigen. 25 of 47 dogs were treated before inhalation challenge with a prostaglandin inhibitor $(90 \mathrm{mg} / \mathrm{kg}$ of aspirin or $2 \mathrm{mg} / \mathrm{kg}$ of indomethacin by intravenous infusion). In response to the challenge, bronchospasm developed in approximately half (responders) of each group reflected by decreases in mean specific respiratory system conductance and arterial oxygen tension. While the dogs were breathing room air, pulmonary vascular resistance remained unchanged after antigen challenge in the responders not given aspirin or indomethacin, but increased significantly and was associated with a lesser degree of arterial hypoxemia in the responders pretreated with either of the prostaglandin inhibitors. Prevention of arterial hypoxemia by oxygen breathing blocked an increase in pulmonary vascular resistance in four pretreated responders. No changes in respiratory mechanics, pulmonary hemodynamics, or arterial blood gases were noted in the 21 dogs who did not develop bronchospasm regardless of whether or not they were pretreated. 12 additional dogs in whom arterial hypoxemia was produced by $10 \%$ oxygen breathing, showed an increase in pulmonary vascular resistance that was not potentiated by pretreatment with aspirin in 6 . We conclude that in acute experimental canine asthma, vasodilator prostaglandins appear to blunt the hypoxic pulmonary vasoconstrictor response, thereby further compromising gas exchange but preventing the development of pulmonary hypertension.
\end{abstract}

\section{INTRODUCTION}

Pulmonary hemodynamic abnormalities in bronchial asthma may be related to alveolar hypoxia secondary

Received for publication 14 February 1977 and in revised form 27 January 1978 . to ventilation-perfusion inequalities, the action of chemical mediators of the asthmatic response on the pulmonary circulation, or the mechanical effects of pulmonary hyperinflation. Acute alveolar hypoxia results in pulmonary vasoconstriction by a direct effect on pulmonary vascular smooth muscle or indirectly via intrapulmonary chemical mediators (1). This response is blunted in patients with portal cirrhosis (2), after infusion of endotoxins (3), and in the bronchospasm-associated hypoxia of experimental canine asthma (4). Infusion of endotoxin may stimulate production of vasodilator prostaglandins and oppose the hypoxic vasoconstriction, because prostaglandin inhibitors prevent this blunted response (5). Synthesis, release and activation of vasoactive chemical mediators including histamine, bradykinin, and prostaglandins occur in extrinsic asthma (6). The synthesis of a vasodilator prostaglandin might serve to maintain the pulmonary vascular bed in a dilated state after antigen challenge (7) and to reduce pulmonary arterial hypertension resulting from alveolar hypoxia $(8,9)$. In this investigation, we studied the effects of prostaglandin inhibitors on hypoxic pulmonary vasoconstriction in an experimental canine asthma model.

\section{METHODS}

59 mongrel dogs (12-34 kg) were anesthetized with 25-50 $\mathrm{mg} / \mathrm{kg}$ pentobarbital sodium intravenously and anticoagulated with 5,000 $\mathrm{U}$ of heparin sulfate given as an intravenous bolus. They were placed in the lateral decubitus position and intubated with an oral cuffed endotracheal tube. Transvenous phrenic nerve stimulation (10) was used to maintain a respiratory rate and tidal volume that resulted in a base-line $\mathrm{pH}$ between 7.35-7.45 $\mathrm{U}$. The dogs inspired either room air, $10 \%$ oxygen, or $80 \%$ oxygen in nitrogen depending on the type of experiment.

Hemodynamic measurements and arterial blood gases. Catheters were placed in the left atrium, the pulmonary artery, and one of the carotid arteries. Pressures at these sites were measured with a strain gauge (type P23, Statham Corp., Puerto Rico) and referenced to the mid-chest level. Pulmonary blood flow was determined with the indicator dilution method by injection 
of indocyanin green into the pulmonary artery and sampling blood withdrawn from the carotid artery with a Gilford densitometer (model 103TR, Gilford Instrument Laboratories Inc., Oberlin, Ohio). An electrocardiogram was continuously recorded. All signals were recorded on an Electronics for Medicine multichannel recorder (model DR 12, Electronics for Medicine, Inc. White Plains, N. Y.). Pulmonary blood flow was calculated on line on a small digital computer (LINC 8, Digital Equipment Corp., Marlboro, Mass.). Pulmonary vascular resistance was defined as the difference between mean pulmonary arterial and left atrial pressures divided by pulmonary blood flow. These hemodynamic measurements were made at functional residual capacity (FRC) ${ }^{1}$ during a short period of apnea (15$20 \mathrm{~s})$. Arterial blood samples drawn anaerobically from the carotid artery catheter were analyzed for $\mathrm{PO}_{2}, \mathrm{PCO}_{2}$, and $\mathrm{pH}$ at $37^{\circ} \mathrm{C}$ (ABL 1, Radiometer Co., Copenhagen, Denmark).

Respiratory mechanics and FRC. FRC was determined using the helium dilution technique. A 1-liter giant syringe was filled with a $10 \%$ helium in air gas mixture and connected to the endotracheal tube at the FRC position. The dog was rebreathed with the syringe at a rate of approximately 30 breaths/ min, and the helium concentration was continuously recorded in the system with a mass-spectrometer (Perkin-Elmer Corp., Instrument Div., Norwalk, Conn.) until a plateau was reached for the final reading.

Respiratory resistance was determined by the forced oscillation method as follows: without previous sighing and immediately after discontinuation of phrenic nerve stimulation, the endotracheal tube was connected via a no. 1 Fleisch pneumotachograph to a tube through which sinusoidal volume changes of $100 \mathrm{ml}$ or less were forced on the respiratory system with a loud speaker at a frequency of $6 \mathrm{~Hz}$. This resulted in peak to peak flow rates of $<0.7$ liter/s. The pressure gradient across the pneumotachograph was measured with a Validyne DP45 (Validyne Engineering Corp., Northridge, Calif.) differential gauge. Tracheal pressure was measured with another Validyne DP45 transducer referenced to atmosphere via a French 8 side-hole catheter introduced through the endotracheal tube. This system showed no phase shifts in the frequency range used in the experiments. Pressure and flow signals were fed into the LINC 8 digital computer for on-line computation of resistance by the method of Goldman et al. (11). A mean resistance value was obtained for a 4 -s period and expressed as specific respiratory system conductance (reciprocal of respiratory system resistance divided by FRC).

Static compliance was measured between $200 \mathrm{ml}$ above FRC and FRC after inflating the lung to 1 liter above FRC with the giant syringe. Transpulmonary pressure was obtained by relating esophageal pressure estimated by the balloon catheter technique to mouth pressure (Validyne DP35 differential gauge). Static lung compliance was divided by FRC and expressed as specific static lung compliance.

Aspirin and indomethacin pretreatment. After initial baseline determinations of hemodynamics, arterial blood gases. FRC, and respiratory mechanics, 31 dogs were pretreated with acetylsalicylic acid (aspirin; Endosprin [Enila Laboratory, Rio de Janeiro, Brazil]) in a dose of $90 \mathrm{mg} / \mathrm{kg}$ diluted with sterile physiologic saline to a volume of $50 \mathrm{ml}(\mathrm{pH}$ of 7.40) and slowly infused into the pulmonary artery over 15 min using a Harvard infusion pump (Harvard Apparatus Co. Inc., Millis, Mass.). Repeat base-line determinations were made 30 and $60 \mathrm{~min}$ after completion of aspirin infusion. In six dogs, serum was obtained $\mathrm{l} \mathrm{h}$ after aspirin infusion for a salicylate level determination (Tilder colorimetric method).

\footnotetext{
${ }^{1}$ Abbreviations used in this paper: FRC, functional residual capacity; $\mathrm{SG}_{\mathrm{rs}}$, specific respiratory system conductance.
}

Seven dogs were pretreated with indomethacin (Indocin, Merck \& Sharp Dohme, West Point, Pa.) in a dose of $2 \mathrm{mg} / \mathrm{kg}$ diluted in $10 \mathrm{ml}$ sterile water containing $10 \mathrm{mg}$ sodium carbonate and infused into the pulmonary artery over $5 \mathrm{~min}$. Repeat measurements were made $60 \mathrm{~min}$ after infusion.

Ascaris suum aerosol challenge. 47 dogs inhaled an aerosol of Ascaris suum extract (Greer Laboratories, Lenoir, N. C.) (12) using a side-arm nebulizer (Vaponefrin INHAL'A'JET, Bedford, Conn.) which produces particles with a mass median diameter of $5.6 \mu \mathrm{m}$ (geometric SD 1.9) (13). The nebulizer was driven by either compressed air or $100 \%$ oxygen depending on the experiment. Less than $10 \mathrm{~min}$ were required for complete nebulization of the prepared solution $\left(5 \mathrm{ml}\right.$ of $10^{-2}$ dilution).

Experiment 1. Of the 16 dogs selected for antigen challenge without aspirin or indomethacin pretreatment, 12 of these breathed room air, and 4 breathed $80 \%$ oxygen. After base-line measurements of respiratory mechanics, FRC, arterial blood gases, and hemodynamics, the dogs were exposed to the aerosol of Ascaris suum extract. $15 \mathrm{~min}$ after nebulization was begun, all measurements were repeated.

Experiment 2. 19 room air-breathing dogs were selected for antigen challenge after pretreatment with either aspirin (12 dogs) or indomethacin (7 dogs). After base-line physiologic measurements, aspirin or indomethacin was administered, and the measurements were repeated as described above. $1 \mathrm{~h}$ later the dogs were exposed to the aerosol of Ascaris suum extract. 15 min after the beginning of nebulization, all measurements were repeated.

12 additional dogs breathing $80 \%$ oxygen were selected for antigen challenge after pretreatment with aspirin. The protocol was the same as above.

Experiment 3. In six dogs, measurements of hemodynamics, arterial blood gases, FRC, and respiratory mechanics were made before and after $15 \mathrm{~min}$ of $10 \%$ oxygen breathing.

Experiment 4. In another six dogs, the same measurements as in experiment 3 were made before and $60 \mathrm{~min}$ after aspirin infusion, and after $15 \mathrm{~min}$ of $10 \%$ oxygen breathing which was started immediately after the postaspirin base-line measurements were completed.

Statistical analysis. Differences between mean values for the different parameters before and after intervention were evaluated in the various groups employing the paired variate of Student's $t$ test. An unpaired $t$ test was used to compare the different groups before and after intervention.

\section{RESULTS}

The mean base-line values for pulmonary hemodynamics, arterial blood gases, FRC, and pulmonary mechanics were comparable among all groups. No changes in FRC or specific static lung compliance were observed in any of the groups after antigen challenge (room air and $80 \%$ oxygen breathing) or during $10 \%$ oxygen breathing. Regardless of whether or not they were pretreated with aspirin or indomethacin, approximately half of the dogs challenged with Ascaris suum responded with bronchospasm (responders) as represented by a decrease in specific respiratory system conductance $\left(\mathrm{SG}_{\mathrm{rs}}\right)$. The others (nonresponders) did not show any significant change in $\mathrm{SG}_{\mathrm{rs}}$ (Fig. 1).

The mean serum salicylate level in 6 of 31 dogs 

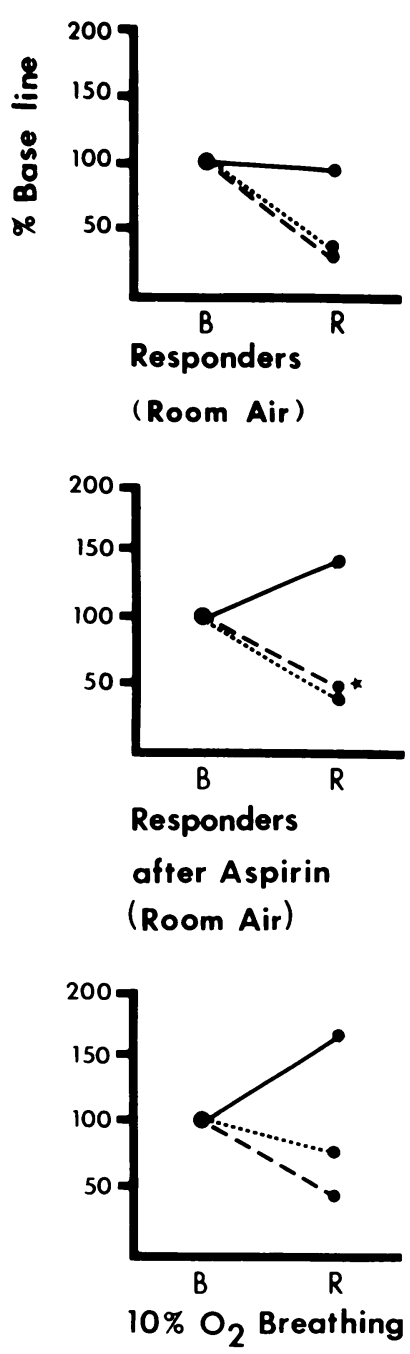

PVR
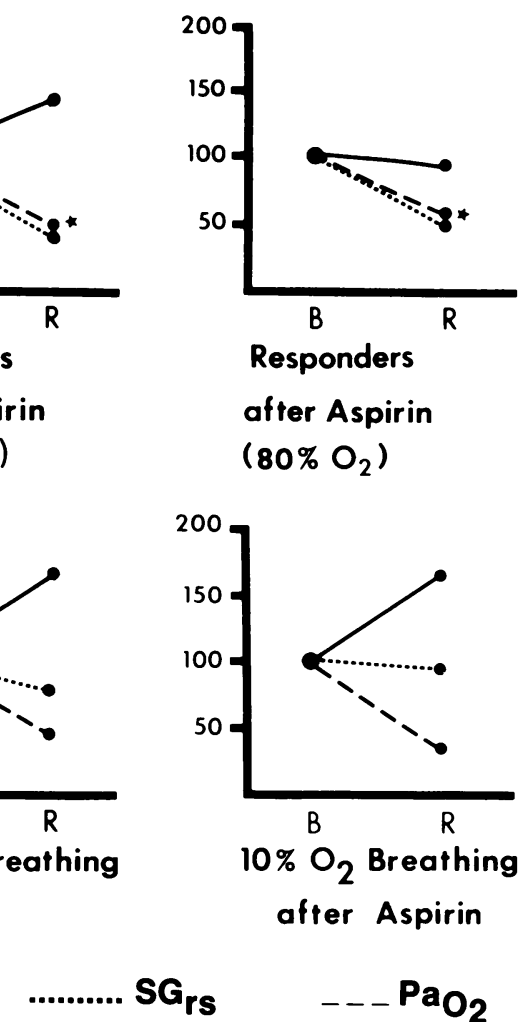

$S G_{r s}$

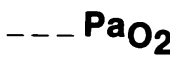

FIGURE l Relative changes in pulmonary vascular resistance (PVR), specific respiratory system conductance $\left(\mathrm{SG}_{\mathrm{rs}}\right)$, and arterial oxygen tension $\left(\mathrm{PaO}_{2}\right)$ before $(B)$ and after $(\mathbf{R})$ intervention in the experimental groups. The following changes are significant: $\mathrm{SG}_{\mathrm{rs}}$ and $\mathrm{PaO}_{2}$ in responders without aspirin (room air) and after aspirin $\left(80 \% \mathrm{O}_{2}\right) ; \mathrm{SG}_{\mathrm{rs}}, \mathrm{PaO}_{2}$, and PVR in responders after aspirin (room air); $\mathrm{PVR}$ and $\mathrm{PaO}_{2}$ in both groups of $10 \%$ oxygen breathing. (Mean $\mathrm{PaO}_{2}$ in responders after aspirin [room air] fell to $48 \mathrm{~mm} \mathrm{Hg}$ compared with 199 $\mathrm{mm} \mathrm{Hg}$ for the responders after aspirin [80\% oxygen].)

pretreated with aspirin was $18.0 \mathrm{mg} / 100 \mathrm{ml}(\mathrm{SD} 3.7)$ immediately before intervention.

Experiment 1 (antigen challenge without aspirin or indomethacin pretreatment). 6 of the 12 animals breathing room air were responders. They showed marked $(P<0.05)$ decreases in mean $\mathrm{SG}_{\mathrm{rs}}$ to $33 \%$ of base line, and mean $\mathrm{PaO}_{2}$ to $31 \%$ of base line. In addition, there was a significant increase in mean $\mathrm{PaCO}_{2}$ and a significant decrease in $\mathrm{pH}$ (Tables I and II). However, mean pulmonary vascular resistance did not change significantly.

In the six nonresponders, no significant changes were seen in pulmonary hemodynamics, FRC, pulmonary mechanics, or arterial blood gas composition.

Four additional responders breathing $80 \%$ oxygen showed a significant decrease in mean $\mathrm{SG}_{\mathrm{rs}}$, but no changes in any of the other parameters.

Experiment 2 (antigen challenge after aspirin or indomethacin pretreatment). In 12 dogs breathing room air, the physiologic measurements were repeated 30 and $60 \mathrm{~min}$ after the aspirin infusion was completed and, except for a mild but significant increase in mean pulmonary arterial pressure in the nonresponders, no other changes from the previous base line were noted (Tables I and II). After antigen challenge, mean $\mathrm{SG}_{\mathrm{rs}}$ decreased significantly to $41 \%$ of the postaspirin base-line value in the responders (six dogs). In addition, there was a significant decrease in mean $\mathrm{PaO}_{2}$ to $49 \%$ of the postaspirin base-line value, along with a significant decrease in $\mathrm{pH}$ and increase in $\mathrm{PaCO}_{2}$. Although the severity of arterial hypoxemia, hypercapnia, and acidosis was significantly less $(P$ $<0.05)$ than in the responders without pretreatment (experiment 1$)$, there was a marked $(P<0.01)$ increase in mean pulmonary vascular resistance to $143 \%$ of the postaspirin base line (Figs. 2 and 3 ).

Except for a slight but significant $(P<0.01)$ reduction in mean systemic arterial pressure in the aspirinpretreated nonresponders, no changes in hemodynamics or arterial blood gases were noted after antigen challenge.

In all four responders in the indomethacin-pretreated group (seven dogs), the observed changes in hemodynamics, arterial blood gases, and respiratory mechanics were similar to the aspirin-pretreated group. After antigen challenge, mean $\mathrm{SG}_{\mathrm{rs}}$ decreased to $23 \%$ and mean $\mathrm{PaO}_{2}$ to $46 \%$ of the postindomethacin base line. The degree of arterial hypoxemia (mean $\mathrm{PaO}_{2}$ $=52.0 \mathrm{~mm} \mathrm{Hg}$ [SD 18.5]) was comparable to the aspirin group and resulted in a marked increase in pulmonary vascular resistance to $187 \%$ of the postindomethacin base line. No statistical analysis was employed in this small group; however, in all individual responders there were marked decreases in $\mathrm{SG}_{\mathrm{rs}}$ and $\mathrm{PaO}_{2}$ associated with an increased pulmonary vascular resistance. These changes were not apparent in the three indomethacin-pretreated nonresponders.

In 12 dogs breathing $80 \%$ oxygen, the physiologic measurements were repeated $60 \mathrm{~min}$ after the aspirin infusion was completed. At this time, no changes from previous base line were noted except for a slight but significant increase in mean carotid arterial pressure and slight but significant decrease $(<10 \%)$ in 
TABLE I

Hemodynamics in 12 Dogs Responding to Ascaris suum Challenge*

\begin{tabular}{|c|c|c|c|c|c|c|c|c|}
\hline & & & $\begin{array}{l}\text { Pulmonary } \\
\text { vascular } \\
\text { resistance }\end{array}$ & $\begin{array}{c}\text { Mean } \\
\text { pulmonary } \\
\text { arterial } \\
\text { pressure }\end{array}$ & $\begin{array}{c}\text { Mean } \\
\text { left } \\
\text { atrial } \\
\text { pressure }\end{array}$ & $\begin{array}{c}\text { Mean } \\
\text { carotid } \\
\text { arterial } \\
\text { pressure }\end{array}$ & $\begin{array}{c}\text { Pulmonary } \\
\text { blood } \\
\text { flow }\end{array}$ & $\begin{array}{l}\text { Heart } \\
\text { rate }\end{array}$ \\
\hline & & & $\mathrm{cm} \mathrm{H}_{2} \mathrm{O} /$ liter/min & $\mathrm{cm} \mathrm{H} \mathrm{H}_{2} \mathrm{O}$ & $\mathrm{cm} \mathrm{H} \mathrm{H}_{2} \mathrm{O}$ & $\mathrm{cm} \mathrm{H} \mathrm{H}_{2} \mathrm{O}$ & liters/min & beats/min \\
\hline \multirow{2}{*}{$\begin{array}{l}\text { Exp. } 1 \\
\quad \text { (Room air) } \\
\quad(n=6)\end{array}$} & Base line & $\begin{array}{l}\text { Mean } \\
\text { (SD) }\end{array}$ & $\begin{array}{c}7.8 \\
(3.5)\end{array}$ & $\begin{array}{l}12 \\
(3)\end{array}$ & $\begin{array}{c}0 \\
(5)\end{array}$ & $\begin{array}{l}156 \\
(43)\end{array}$ & $\begin{array}{c}1.7 \\
(0.8)\end{array}$ & $\begin{array}{l}125 \\
(14)\end{array}$ \\
\hline & $\begin{array}{l}\text { After antigen } \\
\text { challenge }\end{array}$ & $\begin{array}{l}\text { Mean } \\
\quad(\mathrm{SD})\end{array}$ & $\begin{array}{c}7.7 \\
(4.0)\end{array}$ & $\begin{array}{l}17 \\
(8)\end{array}$ & $\begin{array}{c}1 \\
(5)\end{array}$ & $\begin{array}{l}191 \\
(44)\end{array}$ & $\begin{array}{c}2.1 \\
(0.4)\end{array}$ & $\begin{array}{l}111 \\
(10)\end{array}$ \\
\hline \multirow{3}{*}{$\begin{array}{l}\text { Exp. } 2 \\
\quad(\text { Room air }) \\
\quad(n=6)\end{array}$} & Base line & $\begin{array}{l}\text { Mean } \\
\text { (SD) }\end{array}$ & $\begin{array}{c}7.6 \\
(2.3)\end{array}$ & $\begin{array}{l}18 \\
(2)\end{array}$ & $\begin{array}{c}0 \\
(3)\end{array}$ & $\begin{array}{l}204 \\
(44)\end{array}$ & $\begin{array}{c}2.4 \\
(0.5)\end{array}$ & $\begin{array}{l}159 \\
(14)\end{array}$ \\
\hline & $\begin{array}{l}\text { Base line } \\
\text { Post-aspirin }\end{array}$ & $\begin{array}{l}\text { Mean } \\
\text { (SD) }\end{array}$ & $\begin{array}{c}9.2 \\
(2.4)\end{array}$ & $\begin{array}{l}23 \\
(4)\end{array}$ & $\begin{array}{c}3 \\
(3)\end{array}$ & $\begin{array}{l}244 \\
(60)\end{array}$ & $\begin{array}{c}2.2 \\
(0.6)\end{array}$ & $\begin{array}{l}152 \\
(19)\end{array}$ \\
\hline & $\begin{array}{l}\text { After antigen } \\
\text { challenge }\end{array}$ & $\begin{array}{l}\text { Mean } \\
\text { (SD) }\end{array}$ & $\begin{array}{l}13.2 \ddagger \\
(4.1)\end{array}$ & $\begin{array}{c}35 \\
(15)\end{array}$ & $\begin{array}{c}3 \\
(4)\end{array}$ & $\begin{array}{l}222 \\
(67)\end{array}$ & $\begin{array}{c}2.5 \\
(0.9)\end{array}$ & $\begin{array}{l}143 \\
(15)\end{array}$ \\
\hline
\end{tabular}

* Mean values with $1 \mathrm{SD}$ in parentheses.

$\$ P<0.01$; significant difference between subsequent interventions. All other values have no significant difference.

mean FRC. After antigen challenge, mean $\mathrm{SG}_{\mathrm{rs}}$ in six responders decreased significantly from the postaspirin base line by $53 \%$ to a mean 0.61 (liters/s)/(cm $\mathrm{H}_{2} \mathrm{O} /$ liters) (SD 0.23). This was accompanied by a significant decrease in mean $\mathrm{pH}$ with a resulting final value of 7.22 (SD 0.10). However, in contrast to the animals breathing room air, $\mathrm{PaO}_{2}$ exceeded $81 \mathrm{~mm} \mathrm{Hg}$ in all animals after antigen challenge (responders and non-responders), and mean pulmonary vascular resistance did not change. In the six nonresponders who breathed $80 \%$ oxygen, no changes in any of the measured parameters were observed.

Experiment $3(10 \%$ oxygen breathing without aspirin or indomethacin pretreatment) (Table III). In these six animals, a decrease in $\mathrm{PaO}_{2}$ comparable to the values observed in the six responders in experiment 1 resulted in an elevation of mean pulmonary vascular resistance to $162 \%$ of base line $(P<0.05)$. This

TABLE II

Respiratory Mechanics, FRC, and Arterial Blood Gases in 12 Dogs Responding to Ascaris Suum Challenge*

\begin{tabular}{|c|c|c|c|c|c|c|c|c|}
\hline & & & $\mathrm{Pa}_{1_{2}}$ & $\mathrm{~Pa}_{\mathrm{CO}_{2}}$ & $\mathrm{pH}$ & FRC & $\begin{array}{c}\text { Specific } \\
\text { respiratory } \\
\text { system } \\
\text { conductance }\end{array}$ & $\begin{array}{l}\text { Specific } \\
\text { static } \\
\text { lung } \\
\text { compliance }\end{array}$ \\
\hline & & & $m m \mathrm{Hg}$ & $m m \mathrm{Hg}$ & $U$ & liters & $\begin{array}{c}(\text { liters/s) }) \\
\left(\mathrm{cm} \mathrm{H} \mathrm{H}_{2} \mathrm{O} / \text { liters }\right)\end{array}$ & liters $/ \mathrm{cm} \mathrm{H}_{2} \mathrm{O}$ \\
\hline \multirow{2}{*}{$\begin{array}{l}\text { Exp. } 1 \\
\text { Room air } \\
\quad(n=6)\end{array}$} & Base line & $\begin{array}{l}\text { Mean } \\
\text { (SD) }\end{array}$ & $\begin{array}{l}100 \\
(11)\end{array}$ & $\begin{array}{l}27 \\
(6)\end{array}$ & $\begin{array}{c}7.42 \\
(0.07)\end{array}$ & $\begin{array}{c}0.56 \\
(0.18)\end{array}$ & $\begin{array}{c}1.30 \\
(0.27)\end{array}$ & $\begin{array}{c}0.23 \\
(0.10)\end{array}$ \\
\hline & $\begin{array}{l}\text { After antigen } \\
\text { challenge }\end{array}$ & $\begin{array}{l}\text { Mean } \\
\text { (SD) }\end{array}$ & $\begin{array}{l}31 \ddagger \\
(5)\end{array}$ & $\begin{array}{l}45 \S \\
(11)\end{array}$ & $\begin{array}{l}7.27 \S \\
(0.07)\end{array}$ & $\begin{array}{c}0.57 \\
(0.17)\end{array}$ & $\begin{array}{r}0.43 \ddagger \\
(0.18)\end{array}$ & $\begin{array}{c}0.24 \\
(0.14)\end{array}$ \\
\hline \multirow{4}{*}{$\begin{array}{l}\text { Exp. } 2 \\
\text { Room air } \\
\quad(n=6)\end{array}$} & Base line & $\begin{array}{l}\text { Mean } \\
\text { (SD) }\end{array}$ & $\begin{array}{l}104 \\
(12)\end{array}$ & $\begin{array}{l}24 \\
(3)\end{array}$ & $\begin{array}{c}7.48 \\
(0.03)\end{array}$ & $\begin{array}{l}0.48 \\
0.12\end{array}$ & $\begin{array}{c}1.31 \\
(0.61)\end{array}$ & $\begin{array}{c}0.23 \\
(0.04)\end{array}$ \\
\hline & Base line & Mean & 98 & 25 & 7.43 & 0.49 & 1.21 & 0.21 \\
\hline & Post-aspirin & (SD) & (17) & (3) & $(0.06)$ & $(0.19)$ & $(0.85)$ & $(0.05)$ \\
\hline & $\begin{array}{l}\text { After antigen } \\
\text { challenge }\end{array}$ & $\begin{array}{l}\text { Mean } \\
\text { (SD) }\end{array}$ & $\begin{array}{l}48 \ddagger \\
(6)\end{array}$ & $\begin{array}{l}38 \S \\
(10)\end{array}$ & $\begin{array}{r}7.32 \S \\
(0.08)\end{array}$ & $\begin{array}{c}0.42 \\
(0.18)\end{array}$ & $\begin{array}{c}0.50 \S \\
(0.24)\end{array}$ & $\begin{array}{c}0.21 \\
(0.10)\end{array}$ \\
\hline
\end{tabular}

* Mean values with $1 \mathrm{SD}$ in parentheses.

$\$ P<0.01$; difference significant between subsequent interventions.

$\S P<0.05$; difference significant between subsequent interventions.

All other values have no significant difference. 


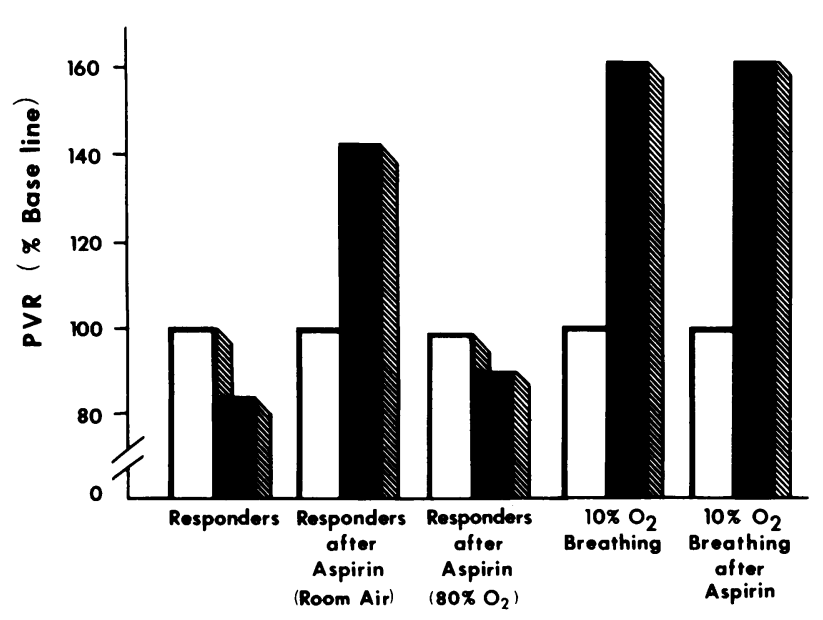

FIgURE 2 Relative changes in mean pulmonary vascular resistance (PVR) in the four experimental groups. Base-line values $(100 \%)$ are represented as open bars; the values after intervention, as solid bars. The changes in the responders after aspirin (room air) and with $10 \%$ oxygen breathing with and without aspirin are significant.

was the result of an increase in mean pulmonary arterial pressure, because no other significant hemodynamic changes occurred. No changes were observed in respiratory mechanics.

Experiment 4 (10\% oxygen breathing with aspirin pretreatment). In these six animals, mean pulmonary arterial and left atrial pressures remained significantly elevated $60 \mathrm{~min}$ after aspirin infusion but pulmonary vascular resistance was not significantly different from

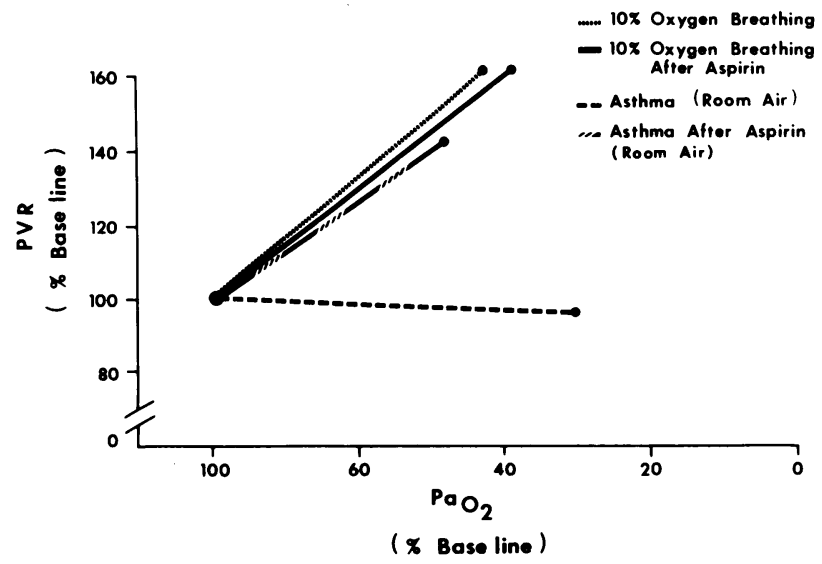

FIgURe 3 Pulmonary vascular resistance (PVR) vs. arterial oxygen tension $\left(\mathrm{PaO}_{2}\right)$ in responders breathing room air (asthma) and after 10\% oxygen breathing with and without aspirin pretreatment. Values are expressed as relative changes from base line. Except for responders breathing room air (asthma) without aspirin pretreatment, the changes in PVR are significant.

base-line values. After 15 min of $10 \%$ oxygen breathing, the decrease in $\mathrm{PaO}_{2}$ was associated with an increase in mean pulmonary vascular resistance to $163 \%$ of the post-aspirin base line $(\mathrm{P}<0.01)$. These changes in $\mathrm{PaO}_{2}$ and pulmonary vascular resistance were not significantly different from those observed in the six dogs who breathed $10 \%$ oxygen without aspirin pretreatment (Figs. 2 and 3). Again, the increase in pulmonary vascular resistance resulted from an increase in mean

TABLE III

Hemodynamics and Arterial Blood Gases in 12 Dogs During 10\% Oxygen Breathing*

\begin{tabular}{|c|c|c|c|c|c|c|c|c|c|}
\hline & & & $\begin{array}{l}\text { Pulmonary } \\
\text { vascular } \\
\text { resistance }\end{array}$ & $\begin{array}{c}\text { Mean } \\
\text { pulmonary } \\
\text { arterial } \\
\text { pressure }\end{array}$ & $\begin{array}{c}\begin{array}{c}\text { Mean } \\
\text { left } \\
\text { atrial } \\
\text { pressure }\end{array}\end{array}$ & $\begin{array}{l}\text { Pulmonary } \\
\text { blood } \\
\text { flow }\end{array}$ & $\mathrm{Pa}_{1_{12}}$ & $\mathrm{~Pa}_{\mathrm{CO}_{2}}$ & $\mathrm{pH}$ \\
\hline & & & $\mathrm{cm} \mathrm{H}_{2} \mathrm{O} /$ liter/min & $\mathrm{cm} \mathrm{H} \mathrm{H}_{2} \mathrm{O}$ & $\mathrm{cm} \mathrm{H}_{2} \mathrm{O}$ & liters/min & $m m \mathrm{Hg}$ & $m m \mathrm{Hg}$ & $U$ \\
\hline \multirow[t]{2}{*}{$\begin{array}{l}\text { Exp. } 3 \\
\quad(n=6)\end{array}$} & Base line & $\begin{array}{l}\text { Mean } \\
\text { (SD) }\end{array}$ & $\begin{array}{c}6.3 \\
(0.15)\end{array}$ & $\begin{array}{l}17 \\
(5)\end{array}$ & $\begin{array}{c}4 \\
(4)\end{array}$ & $\begin{array}{c}2.2 \\
(0.6)\end{array}$ & $\begin{array}{c}88 \\
(10)\end{array}$ & $\begin{array}{l}27 \\
(5)\end{array}$ & $\begin{array}{c}7.46 \\
(0.04)\end{array}$ \\
\hline & $\begin{array}{r}10 \% \text { oxygen } \\
\text { breathing }\end{array}$ & $\begin{array}{l}\text { Mean } \\
\quad(\mathrm{SD})\end{array}$ & $\begin{array}{l}10.2 \ddagger \\
(3.3)\end{array}$ & $\begin{array}{l}29 \ddagger \\
(12)\end{array}$ & $\begin{array}{c}5 \\
(6)\end{array}$ & $\begin{array}{c}2.4 \\
(0.6)\end{array}$ & $\begin{array}{c}38 \S \\
(7)\end{array}$ & $\begin{array}{l}23 \\
(4)\end{array}$ & $\begin{array}{c}7.48 \\
(0.03)\end{array}$ \\
\hline \multirow[t]{3}{*}{$\begin{array}{l}\text { Exp. } 4 \\
\quad(n=6)\end{array}$} & Base line & $\begin{array}{l}\text { Mean } \\
\quad(\mathrm{SD})\end{array}$ & $\begin{array}{c}8.6 \\
(4.5)\end{array}$ & $\begin{array}{l}14 \\
(4)\end{array}$ & $\begin{array}{c}1 \\
(2)\end{array}$ & $\begin{array}{c}1.9 \\
(0.7)\end{array}$ & $\begin{array}{r}108 \\
(6)\end{array}$ & $\begin{array}{l}27 \\
(8)\end{array}$ & $\begin{array}{c}7.44 \\
(0.07)\end{array}$ \\
\hline & $\begin{array}{l}\text { Base line } \\
\text { post-aspirin }\end{array}$ & $\begin{array}{l}\text { Mean } \\
\quad(\mathrm{SD})\end{array}$ & $\begin{array}{c}9.1 \\
(3.2)\end{array}$ & $\begin{array}{c}27 \ddagger \\
(10)\end{array}$ & $\begin{array}{c}6 \ddagger \\
(4)\end{array}$ & $\begin{array}{c}2.5 \\
(0.7)\end{array}$ & $\begin{array}{c}95 \\
(13)\end{array}$ & $\begin{array}{l}31 \\
(3)\end{array}$ & $\begin{array}{r}7.39 \\
(0.04)\end{array}$ \\
\hline & $\begin{array}{c}10 \% \text { oxygen } \\
\text { breathing }\end{array}$ & $\begin{array}{l}\text { Mean } \\
\text { (SD) }\end{array}$ & $\begin{array}{l}14.8 \S \\
(5.2)\end{array}$ & $\begin{array}{l}41 \ddagger \\
(7)\end{array}$ & $\begin{array}{c}4 \\
(6)\end{array}$ & $\begin{array}{c}2.6 \\
(0.8)\end{array}$ & $\begin{array}{l}37 \$ \\
(8)\end{array}$ & $\begin{array}{l}29 \\
(7)\end{array}$ & $\begin{array}{c}7.42 \\
(0.06)\end{array}$ \\
\hline
\end{tabular}

* Mean values with $1 \mathrm{SD}$ in parentheses.

$\ddagger P<0.05$; difference significant between subsequent interventions.

$\S P<0.01$; difference significant between subsequent interventions.

All other values have no significant difference. 
pulmonary arterial pressure. As in the animals breathing $10 \%$ oxygen without aspirin pretreatment, no changes occurred in FRC and respiratory mechanics.

\section{DISCUSSION}

Booth et al. (12), Patterson et al. (14), and Gold et al. (15) have studied the immunological and mechanical features of experimental canine asthma induced by inhalation of Ascaris suum extract and described the transient changes in airway mechanics and ventilation. We chose this model for the study of the hypoxic pulmonary vasoconstrictor response and its modification by vasoactive mediators of the asthmatic response for the following reasons. First, antigen-induced bronchospasm in sensitized dogs differs from human bronchial asthma in that no pulmonary hyperinflation is observed, perhaps related to the use of general anesthesia (16). Therefore, the canine asthma represents a convenient model to study the effects of alveolar hypoxia and chemical mediators on the pulmonary circulation without having to consider the added effects of altered respiratory mechanics on pulmonary hemodynamics (17). To eliminate the vascular effects of increased alveolar pressures, the hemodynamic measurements were made during a short period of apnea, a method which has previously been shown to result only in minimal increases in pulmonary arterial pressure of $<1 \mathrm{~cm} \mathrm{H}_{2} \mathrm{O}$ (18). Second, transvenous phrenic nerve stimulation can be easily carried out in anesthetized dogs, thereby avoiding the effects of positive pressure ventilation on the pulmonary circulation (18).

The hypoxia during bronchospasm in the antigenchallenged dogs resulted from a combination of alveolar hypoventilation and ventilation-perfusion inequalities. Although alveolar gas composition was not measured in these studies, the observed magnitude of the decrease in $\mathrm{PaO}_{2}$ after antigen challenge was felt to be an expression of marked mean alveolar hypoxia under these experimental conditions where the induced alterations in gas exchange resulted from airway obstruction.

Hypoxia and acidosis produce variable changes in pulmonary vascular resistance in anesthetized dogs $(19,20)$, whereas in conscious dogs the resulting increase in pulmonary vascular resistance is more consistent (21). Even though general anesthesia was used in our experiments, it probably did not alter the significance of the results because all dogs with arterial hypoxemia (secondary to bronchospasm or $10 \%$ oxygen breathing) received the same anesthetic agent in similar doses. Likewise, changes in the responses to hypoxia with time (9) were eliminated by making all measurements $15 \mathrm{~min}$ after the onset of bronchial challenge or $10 \%$ oxygen breathing. Only one episode of hypoxia was produced in any given animal to avoid the potentiation of hypoxic pulmonary vasoconstriction by repetitive exposure to low oxygen concentrations $(22)$.

Using the experimental canine asthma model, we previously showed that, in contrast to hypoxia induced by $10 \%$ oxygen breathing or mechanical airway obstruction with beads, hypoxia associated with induced asthma does not lead to an increase in pulmonary vascular resistance (4). This suggested that elaboration of vasodilator chemical mediators during the asthmatic attack might have prevented the expected hypoxiarelated pulmonary vasoconstriction. Prostaglandins are known to be synthesized after antigen challenge in rat, guinea pig, and human lung tissues $(23,24)$ and therefore might play such a role. Although aspirin can exert inhibitory and other effects on enzyme and cellular systems, moderate concentrations of aspirin achieved by therapeutic dosages selectively inhibit prostaglandin synthesis $(25,26)$. The aspirin and indomethacin dosages used and serum aspirin concentrations achieved in our study are comparable to those used in other canine $(27)$ and human $(28,29)$ studies. All animals received heparin, a substance which may modify platelet aggregation and the chemical mediators released from the lungs (30); therefore, the remote possibility that heparin interfered directly with aspirin or indomethacin as a prostaglandin inhibitor cannot be excluded on the basis of our experiments. Prostaglandin inhibitors (31) have been helpful in studying the role of prostaglandins in the regulation of bronchial and pulmonary vascular smooth muscle tone. For example, asthmatic patients have increased sensitivity to inhaled prostaglandin $F_{2 \alpha}$, a potent bronchial smooth muscle constrictor, and it is now felt that endogenous, locally produced prostaglandin $F_{2 \alpha}$ may play a contributing role in the pathogenesis of bronchial asthma (32). Also, prostaglandin inhibitors can antagonize the contraction of isolated human bronchial muscle by prostaglandin $F_{2 \alpha}(33)$. This apparently beneficial effect of aspirin-like drugs is of interest in view of other reports on the use of prostaglandin inhibitors in the treatment of asthmatic patients (34), as well as in experimental asthma (35). It has been demonstrated that prostaglandin inhibitors can modify the resting tone of certain isolated smooth muscle preparations including pulmonary vessels (7, $36,37)$. Most recently, for example, aspirin and indomethacin have been used successfully to promote vasoconstriction of a patent ductus arteriosus in an infant (29). We observed in our dogs that after aspirin or indomethacin infusion into the pulmonary artery there was an immediate rise in pulmonary arterial pressure and a slight increase in pulmonary vascular resistance lasting 30-60 min. These findings also suggest a modification of pulmonary vasomotor tone by prostaglandin inhibition under normoxic conditions. 
The role of prostaglandins in the hypoxic pulmonary vasoconstrictor response has been controversial. Although it was initially reported that aspirin reduces the hypoxic vasoconstrictor response (38), subsequent studies have shown opposite results, namely, a potentiation of hypoxic vasoconstriction by prostaglandin inhibition (7, 39, 40). Recently, it has been demonstrated that the progressively diminishing hypoxic pulmonary vasoconstriction occurring with repeated hypoxic challenges in blood-perfused isolated dog lungs can be reversed by aspirin administration (41). It has also been suggested (27) that aspirin may only potentiate a submaximal hypoxic vasoconstrictor response. If our dogs breathing $10 \%$ oxygen responded maximally to hypoxia, this may explain why we were unable to demonstrate a potentiation of the hypoxic pulmonary vasoconstrictor response by aspirin pretreatment.

Whereas the role of prostaglandins in the pulmonary vascular response to low inspired oxygen concentrations may not have been established, prostaglandin inhibition has been clearly shown to unmask the blunted hypoxic pulmonary vasoconstriction after endotoxin infusion (5). Similarly, the failure of pulmonary vasoconstriction in bronchospasm-associated hypoxia in our canine asthma model seems to result from the presence of vasodilator prostaglandins such as prostaglandin $E_{2}$ or $I_{2}$, because pretreatment by aspirin or indomethacin was capable of unmasking the hypoxic pulmonary vasoconstrictor response. That the increase of pulmonary vascular resistance in the responders was due to hypoxia and not to other mechanisms is strongly suggested by the absence of pulmonary vasoconstriction in the responders in whom hypoxia was prevented by oxygen administration. Whether vasodilator prostaglandins are synthesized by constricted airway smooth muscle (42) or as part of the generalized asthmatic chemical mediator response after antigen challenge (6) cannot be concluded from these experiments.

For comparable degrees of bronchospasm, we observed a significantly lesser decrease in $\mathrm{PaO}_{2}$ after antigen challenge in the aspirin- and indomethacinpretreated responders compared with the responders without pretreatment, probably related to a more even matching of ventilation and perfusion when hypoxic pulmonary vasoconstriction was allowed to develop. Thus, elaboration of vasodilator prostaglandins in bronchial asthma might prevent the development of pulmonary arterial hypertension seondary to alveolar hypoxia at the expense of further compromising gas exchange and worsening arterial hypoxemia.

\section{ACKNOWLEDGMENTS}

We wish to thank Mr. Michael Reinhart for his technical assistance.
This work was supported in part by National Heart, Lung, and Blood Institute grant HL10622.

\section{REFERENCES}

1. Fishman, A. P. 1976. Hypoxia on the pulmonary circulation. Circ. Res. 38: 221-231.

2. Daoud, F. S., J. T. Reeves, and J. W. Schaefer. 1972. Failure of hypoxic pulmonary vasoconstriction in patients with liver cirrhosis. J. Clin. Invest. 51: 1076-1080.

3. Reeves, J. T., and R. F. Grover. 1974. Blockade of acute hypoxic pulmonary hypertension by endotoxin. $J$. Appl. Physiol. 3: 328-332.

4. Wanner, A., M. Friedman, and H. Baier. 1977. Study of the pulmonary circulation in a canine asthma model. Am. Rev. Respir. Dis. 115: 241-250.

5. Weir, E. K., J. Mlczoch, J. T. Reeves, and R. F. Grover. 1976. Endotoxin and prevention of hypoxic pulmonary vasoconstriction. J. Lab. Clin. Med. 88(6): 975-983.

6. Austen, K. F., and R. P. Orange. 1975. Bronchial asthma: the possible role of the chemical mediators of immediate hypersensitivity in the pathogenesis of subacute chronic disease. Am. Rev. Respir. Dis. 112: 423-436.

7. Kadowitz, P. J., B. M. Chapnick, P. D. Joiner, and A. L. Hyman. 1975. Influence of inhibitors of prostaglandin synthesis on the canine pulmonary vascular bed. Am. J. Physiol. 229: 941-946.

8. Vaage, J., L. Bjertnaes, and A. Hauge. 1975. The pulmonary vasoconstrictor response to hypoxia: effects of inhibitors of prostaglandin biosynthesis. Acta Physiol. Scand. 95: 95-101.

9. Weir, E. K., I. F. McMurtry, A. Tucier, J. T. Reeves, and R. F. Grover. 1976. Prostaglandin synthetase inhibitors do not decrease hypoxic pulmonary vasoconstriction. J. Appl. Physiol. 41: 714-718.

10. Wanner, A., and M. A. Sackner. 1973. Transvenous phrenic nerve stimulation in anesthetized dogs. J. Appl. Physiol. 34: 489-494.

11. Goldman, M., R. J. Knudson, J. Mead, N. Peterson, J. R. Schwaber, and M. E. Whol. 1970. A simplified measurement of respiratory resistance by forced oscillation. $J$. Appl. Physiol. 28: 113-116.

12. Booth, B. H., R. Patterson, and C. H. Talbot. 1970. Immediatetype hypersensitivity in dogs: cutaneous anaphylactic and respiratory responses to Ascaris. J. Lab. Clin. Med. 76: $181-189$.

13. Mercer, T. T., R. F. Goddart, and R. L. Flores. 1965 Output characteristics of several commercial nebulizers. Ann. Allergy. 23: 314-325.

14. Patterson, R., C. J. Mellies, J. F. Kelly, and K. E. Harris. 1974. Airway responses of dogs with ragweed and Ascaris hypersensitivity. Chest. 65: 488-492.

15. Gold, W. M., G. F. Kessler, U. C. Yu, and O. L. Frick. 1972. Pulmonary physiologic abnormalities in experimental asthma in dogs. J. Appl. Physiol. 33: 496-501.

16. Dain, D., and W. M. Gold. 1975. Mechanical properties of the lungs in conscious allergic dogs. J. Appl. Physiol. 38: $96-100$.

17. Whittenberger, J. L., M. McGregor, E. Berglund, and H. G. Borst. 1960. Influence of state of inflation of the lung on pulmonary vascular resistance. J. Appl. Physiol. 15: $878-882$.

18. Wanner, A., S. Zarzecki, and M. A. Sackner. 1975. Effects of lung inflation on pulmonary arterial blood volume in intact dogs. J. Appl. Physiol. 38: 675-680.

19. Sackner, M. A., D. H. Will, and A. B. DuBois. 1966. The site of pulmonary vasomotor activity during hypoxia and serotonin administration. J. Clin. Invest. 45: 112-121. 
20. Thilenius, O. G. 1966. Effect of pulmonary circulation of dogs to acute hypoxia. J. Appl. Physiol. 21: 901-904.

21. Thilenius, O. G., and C. Derenzo. 1972. Effects of acutely induced changes in arterial $\mathrm{pH}$ on pulmonary vascular resistance during normoxia and hypoxia in awake dogs. Clin. Sci. (Oxf.). 42: 277-287.

22. Unger, M., M. Atkins, W. A. Briscoe, and T. K. C. King. 1977. The potentiation of the pulmonary vascular response with repeated intermittent hypoxia. J. Appl. Physiol. 43: 662-667.

23. Piper, P. N., and J. R. Vane. 1971. The release of prostaglandins from lung and other tissues. Ann. N. Y. Acad. Sci. 180: 363-385.

24. Piper, P. J. 1973. Substances released from passively sensitized human lung tissue during challenge. Int. Arch. Allergy Appl. Immunol. 45: 87-89.

25. Flower, R. J. 1974. Drugs which inhibit prostaglandin biosynthesis. Pharmacol. Rev. 26: 33-67.

26. Vane, J. 1974. Mode of action of aspirin and similar compounds. In Prostaglandin Synthetase Inhibitors. H. J. Robinson and J. R. Vane, editors. Raven Press, New York. 155-163.

27. Hales, C., E. Rouse, and H. Kazemi. 1976. Effect of aspirin on the variability of alveolar hypoxic vasoconstriction in the dog. Fed. Proc. 35: 792A. (Abstr.)

28. Norby, L., R. Lentz, W. Flamenbaum, and P. Ranwell. 1976. Prostaglandins and aspirin therapy in Bartter's syndrome. Lancet. II: 604-606.

29. Heymann, M. A., A. M. Rudolph, and N. H. Silverman. 1976. Closure of the ductus arteriosus in premature infants by inhibition of prostaglandin synthesis. N. Engl. J. Med. 295: 530-533.

30. Weir, E. K., J. Mlczoch, J. Seavy, J. J. Cohen, and R. F. Grover. 1976. Platelet antiserum inhibits hypoxic pulmonary vasoconstriction in the dog.J. Appl. Physiol. 41(2): 211-215.
31. Vaner, J. R. 1971. Inhibition of prostaglandin synthesis as a mechanism of action for aspirin like drugs. Nat. New Biol. 231: 232-235.

32. Mathe, A. A., P. Hedqvist, A. Holmgren, and N. Svanborg. 1973. Bronchial hyperreactivity to prostaglandin $F_{2 \alpha}$ and histamine in patients with asthma. Br. Med.J. 1: 193-196.

33. Sweatman, W. J. F., and H. O. J. Collier. 1968. Effects of prostaglandins on human bronchial muscle. Nature (Lond.). 217: 69 .

34. Jackson, R. H., W. J. Raymer, and R. L. Etter. 1968. New therapy in bronchial asthma. J. Kans. Med. Soc. 69: 474-478.

35. Collier, H. O. J., A. R. Hammond, and B. Whiteley. 1963. Antianaphylactic action of acetylsalicylate in guinea pig lung. Nature (Lond.). 200: 176-178.

36. Altura, B. M., and B. T. Altura. 1976. Vascular smooth muscle and prostaglandins. Fed. Proc. 35: 2360-2366.

37. Messina, E. J., R. Weiner, and G. Kaley. 1976. Prostaglandins and local circulatory control.Fed.Proc. 35: 2367-2375.

38. Said, S. 1974. Pulmonary alveolar hypoxia: release of prostaglandins and other humoral mediators. Science (Wash. D. C.). 185: 1181-1183.

39. Weir, E. K., J. T. Reeves, and R. F. Grover. 1974. Meclofenamate and indomethacin augment the pulmonary pressor response to hypoxia and exogenous prostaglandin $\mathrm{F}_{2 \alpha}\left(\mathrm{PGF}_{2 \alpha}\right)$. Physiologist. 17: 355A. (Abstr.)

40. Hales, C., E. Rouse, and H. Kazemi. 1976. Influence of aspirin and indomethacin in alveolar hypoxic vasoconstriction in the isolated lung. Am. Rev. Respir. Dis. 13(Pt. 2): 248A. (Abstr.)

41. Alexander, J. M., M. D. Nyby, and K. A. Jasberg. 1977. Prostaglandin synthesis inhibition restores hypoxic pulmonary vasoconstriction. J. Appl. Physiol. 42(6): 903-908.

42. Said, S. 1973. The lung in relation to vasoactive hormones. Fed. Proc. 32: 1972-1976. 